石油技術協会誌 第 62 卷 第 4 号 (平成 9 年 7 月)

JOURNAL OF THE JAPANESE ASSOCIATION FOR PETROLEUM TECHNOLOGY

VOL. 62 , NO. 4 (July, 1997)

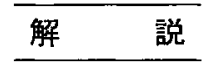

渦鞭毛藻化石の石油探鉱への利用*

\author{
栗 田裕 司**
}

(Received September 2, 1996 ; accepted January 28, 1997)

\title{
Fossil dinoflagellate cysts and their application to petroleum exploration
}

\begin{abstract}
Hiroshi Kurita
Abstract : Dinoflagellate cysts are organic-walled, acid-resistant microfossils which are common in marine sediments from Triassic to Recent. The significance of these microfossils has ever been emphasized in oil industry as they contribute well to formation correlation and paleoenvironmental analyses. This article reviews biological aspects and geological application of fossil dinoflagellate cysts.
\end{abstract}

Key words: dinoflagellate cysts, biostratigraphy, ecology, sedimentary environment, Mesozoic, Cenozoic

\section{1.はじめに}

渦鞭毛藻（うずベんもうそう）化石は，1960年代以 降, 欧州・北米・アフリカ・オーストラリアなどさまざ まな地域の石油探鉱に役立てられてきた。これに対し日 本国内に拉てて，基礎研究の遅れから，この化石を用 いた坑井間対比などの実用的な利用が行われてこなかっ た。近年になって日本国内でも基礎的な研究が進展し， 地域的な層序問題の解決や基礎試錐での層序解析なよ゙に おいて実用的な成果が得られている。渦鞭毛藻化石は, 今後も国内外を問わず石油探鉱における有用な化石層序 ッールとしてますます利用されていくであろう。小論で は，国内の石油地質技術者には比較的なじみの薄い渦鞭 毛藻化石の利用について，その産状の理解の基礎となる 生物学的側面を含め, 一般的な特質を紹介する。

$*$ 平成 8 年 6 月 5 日, 平成 8 年度石油技術協会春季講演会地 質・探鉱部門シンポジウム「石油地質学に対する基礎試錐の 貢献」で一部講演 Presented partially at the 1996 JAPT Geology and Exploration Symposium entitled "MITI exploratory drilling program-their contribution to new exploration technology" held in Akita, June 5, 1996.

**石油資源開発株式会社技術研究所 JAPEX Research Center, Japan Petroleum Exploration Co., Ltd.

Copyright (C) 1997, JAPT

\section{2. 渦鞭毛藻の生態・生活環と化石化過程}

渦鞭毛藻 (dinoflagellates ダイノフラジェレート) は, 原生生物界に属する単細胞生物の一員で, 現在の海 洋では珪藻に次いで主要な第一次生産者である。珮鞭毛 藻は, 赤潮の主要原因生物のひとつでああり, 一部の種 類は強い毒性を持つことが知られている。そのために, 水産・水質環境関係では特別な関心が寄せられている。 また，渦鞭毛藻の一部は夜光虫としても知られる。

現生渦鞭毛藻の個々の種が示す生態はきわぬて多様性 に富んでいる。例えば，栄養生態の上からは大きく見 て, 藻類でありながら, 光合成をするものは約半数で, 他の半数は摄食による従属栄養である。また，プランク トン生活を営むもののほかに，他の生物（有孔虫やサン ヨ゙など）の共生あるい槣生生活者亡して生きるあのも 多い。生息環境の観点からは，現生渦鞭毛藻はあらゆる 海域に生息しているほか，淡水生の屯の屯数多く存在す る。さらに形態の上からは，特徴的な鎧板構造を持つあ の (armoured 有款) と，持たない屯の (unarmoured 無款）とがある。以上のほか，生物学的に際立ったさま ざまな特質を持つ渦鞭毛藻は, 生物学の面でも大いに注 目されている（例えば，井上，1996；村田，1996）。

古生物学的に最も重要な点は, 渦鞭毛藻の一部が, 遊 
泳期と休眠期を交互に繰り返す生活環を持ち，休眠期に 強靯な有機質膜を持つシスト（cyst 休眠胞子）を形成 することである（図 1)。遊泳期の殼はセルロース質で， 化石としては全く残存しえないのに対し，有機質シスト は化石として良く保存されうる（Evitt, 1961 ; 松岡, 1980）。シストは運動性を持たず，自然沈下して水底に 着底し，成熟したのちに発芽して次世代の遊泳体を生ず る。化石化するのは，発芽したあとのシストの「ぬけが ら」である。このような性質から，㵝鞭毛藻化石は地質 時代の渦鞭毛澡群集のうち、シストを形成したグループ のみを代表している。現生渦鞭毛藻の観察によれば，ひ とつの種の遊泳体とシストとは形態がかなり異なる場合 が多い。

渦鞭毛藻の体組織を構成する要素のうち，化石として 残存可能なるのには有機質のシストのほかに鉱物質の骨 格部屯知られるものの，多くの場合渦鞭毛藻化石といえ ば有機質シスト化石を指す。したがって渦鞭毛藻化石の 研究は，有機質微化石全般を扱うパリノロジーの一分野 としても位置づけられる。渦鞭毛藻化石を岩石から分 離・濃集するための試料前処理法は花粉化石分析の場合 とほぼ同一で，通常は花粉化石分析と同じプレパラート を渦鞭毛藻化石分析に使用する。ただし一般的な海成堆
積物から濃縮された有機物中での渦鞭毛藻化石の存在比 は，花粉胞子化石よりもかなり低いため，渦鞭毛藻化石 の分析には質の高い前処理が必要である。なお近年，渦 鞭毛藻の石灰質シス卜化石の古生物学的重要性も指摘さ れている (Fütterer, 1978; Matsuoka et al., 1990)。

渦鞭毛藻の休眠から発芽に至る過程の生態にはいまだ 不明な点が多い。多くの渦鞭毛藻は光合成を行うことか ら, 発芽後の個体は有光層に到達する必要があると推察 される。つまり，ある程度より浅い水深でなければ発芽 は不可能と思わ机るため，佩鞭毛澡化石の源生息域は一 般には浅海（内湾～陸棚）域と考えられる。現実には, 渦鞭毛藻化石は浅海成堆積物のみならずタービダイトな どの深海成泥岩からむかなり高い頻度で産出する。この 事実は, 渦鞭毛藻シストの化石化過程には表層堆積物の 二次移動に伴う拡散の影響が強いことを示唆している。 深海に設置されたセディメント・トラップから報告され ている渦鞭毛藻シスト群集は，二次移動による拡散の存 在を証明するむのであろう（松岡，1989；Dale, 1992）。

ともあれ，一般に渦鞭毛藻化石は浅海帯中部から上部 漸深海帯の堆積物に最も多産する傾向があり，その化石 層序は，上り陸域側に起源を持つ化石の記録（花粉・胞 子など）と，より海洋側に主たる分布を持つ化石の記録

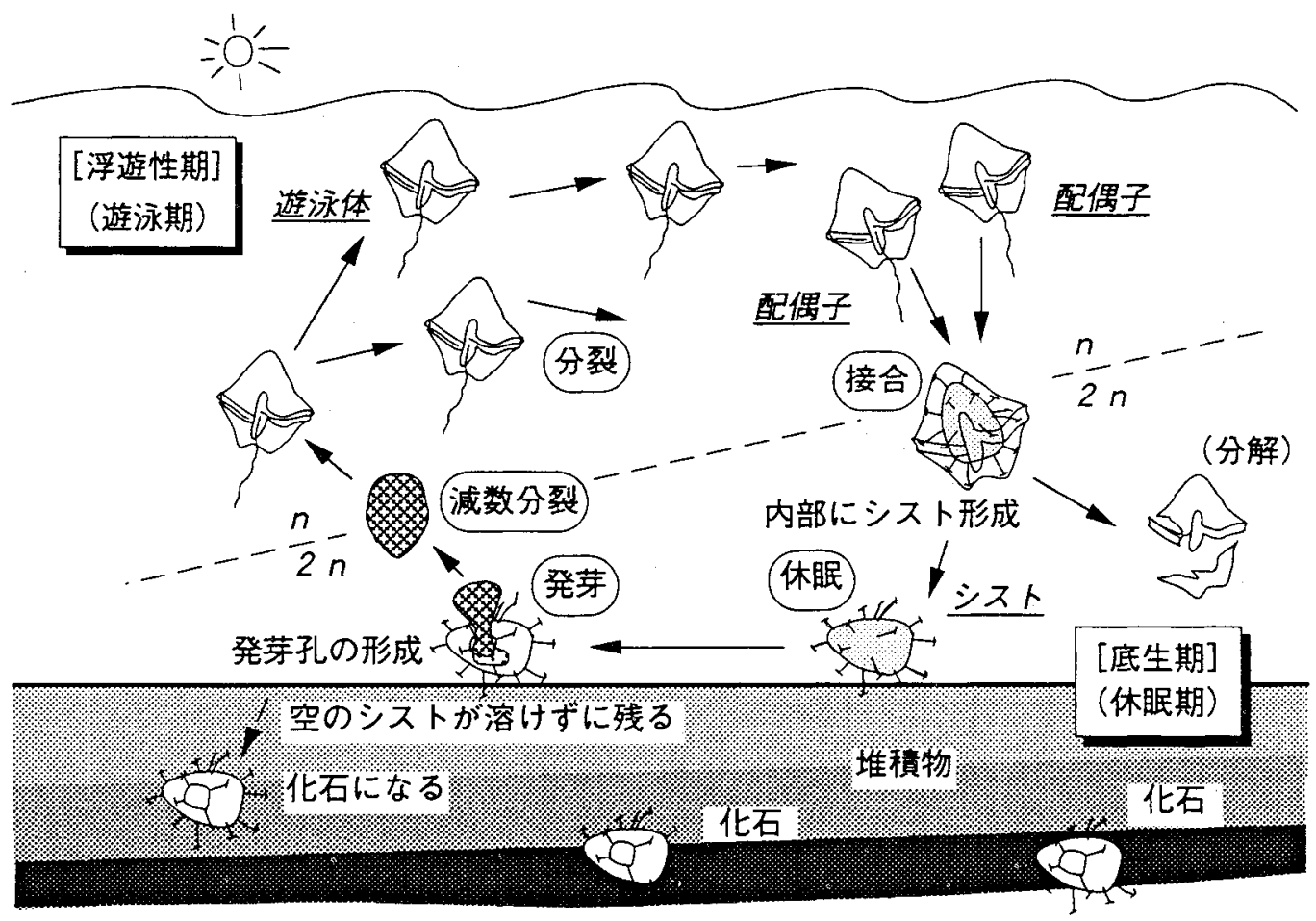

図 1 シストを形成する現生渦鞭毛藻における生活環モデル Evitt（1985）をもとに改变。 
（浮遊性有孔虫や石死質ナンノプランクトンなど）とを 結びつける役割を担っている（Stover et al., 1996）。

\section{3. 渦鞭毛藻化石の形態}

渦鞭毛澡化石の形態には大別して, 長い棘ないし突起 物を持つ chorate 型と, 顕著な突起物を持たない proximate 型との 2 型がある（図 2 ）。渦鞭毛藻化石の大き な特徵は，シストが発芽する際に形成された発芽孔 (archeopyle) を持っていることで, この孔の殸上の位 置や形態が，分類上の重要な基準のひとつとなってい る。洬鞭毛藻化石の形態は, ほとんどの場合上下・左右 に非対称であるほか, 中央部付近の横溝や上下の頂部で の突起の発達が，しばしば見られる。化石個体の大きさ は一般に 20〜200 $\mu \mathrm{m}$ 程度である。渦鞭毛藻化石の分 類・同定に関する総合的な文献として, Eisenack and Kjellström (1964-1975), Lentin and Williams (1976, 1993), Stover and Evitt (1978), Evitt (1985), Jan du Chêne et al. (1986), Stover and Williams (1987), Fensome et al. (1991-1995), Williams et al. (1993), Fensome et al. (1993) なよ゙がある。また渦鞭毛藻化石 に関して簡潔にまとめた最近の教科書には, Goodman (1987), Edwards (1993), Stover et al. (1996) なよ゙ がある。

\section{4. 渦鞭毛藻化石層序とその利点}

渦鞭毛藻化石の研究, 特にその化石層序は, 他の微化 石と同様石油探鉱と密接に関係しつつ発展してきた歴史 を持つ。その初期の舞台は，1960年代７0年代の主に北 大西洋地域（北海, Scotian Shelf な゙）であった。現 在, 全世界には数百人規模の渦鞭毛藻化石研究者・技術 者が活躍しているが，その半数近くは石油探鉱に関連し
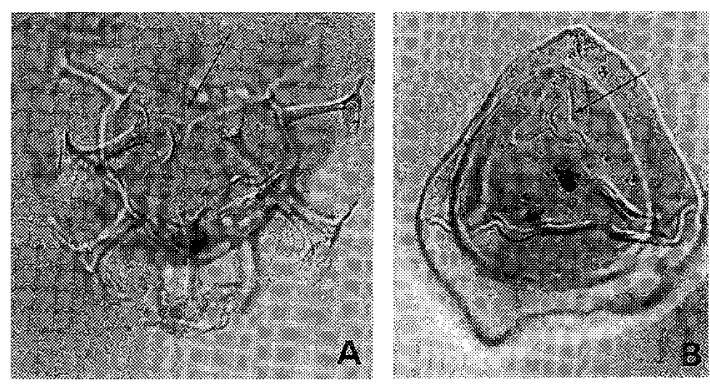

図 2 渦鞭毛藻化石 0 代表的 2 型と発芽孔

開口している部分 (矢印) が発芽孔。

A : chorate 型, Areosphaeridium diktyoplokus (始新世)，棘を含む横の長さ $=90 \mu \mathrm{m}$

$\mathrm{B}$ ： proximate 型, Isabelidinium $\mathrm{sp}$. (後期白亜 紀), 横の長さ $=62 \mu \mathrm{m}$
た課題に従事している。

渦鞭毛藻化石は三畳紀から形態的分化が始まり，その 層位分布は現世まで途切れることなくつながっている。 ながも種の多様性が高い期間は，ジュラ紀中期から始 新世までの時代である（㐿 3 ）。渦鞭毛藻化石層序のこ れまでの利用は，主としてこの区間を対象に行われてき た。咸 4 は, 渦鞭毛藻化石の多様性が特に高い区間のひ とつである白亜系オーブ階を中心とした渦鞭毛藻化石層 序区分の例である。さらに近年では, 漸新統〜鮮新統の 化石層序の研究手盛んとなっている（例えばWrenn et al., 1986 ; Head and Wrenn, 1992 ; de Verteil and Norris, 1996)。

渦鞭毛藻化石の個々の種の層位分布，すなわち広域的 な種の出現・消隇などの基準面（datum）は，他の微 化石と同椂に, 深海底コアや地表・坑茾など陸上セク ションでの産状と，他の示準化石・年代資料とを総合化 することにより求められている。渦鞭毛藻化石層序によ る堆穦物の年代推定は，第一に，そのようにして決めら れた基準面に基づいて行う。さらに，地域ごとに群集組 成の層位変化を明らかにして骠準化石層序区分を確立す ることにより, 各地域内での対比や間接的な年代推定に 役立てることができる。渦鞭毛藻化石層序区分として， かつて汎世界的な適用を念頭に置いたものが試みられた ことがあるが (Williams and Bujak, 1985), 渦鞭毛澡 化石の群集組成には地域性が現れやすいことから，過剩 に広い地理的範囲を想定した化石帯区分は必ずしも実用 的ではない（Edwards，1993）。例えば，白西紀の北大 西洋の東西両岸では, 緯度方向に群集が分別するような 古生物地理区が存在していたとされている（Lentin

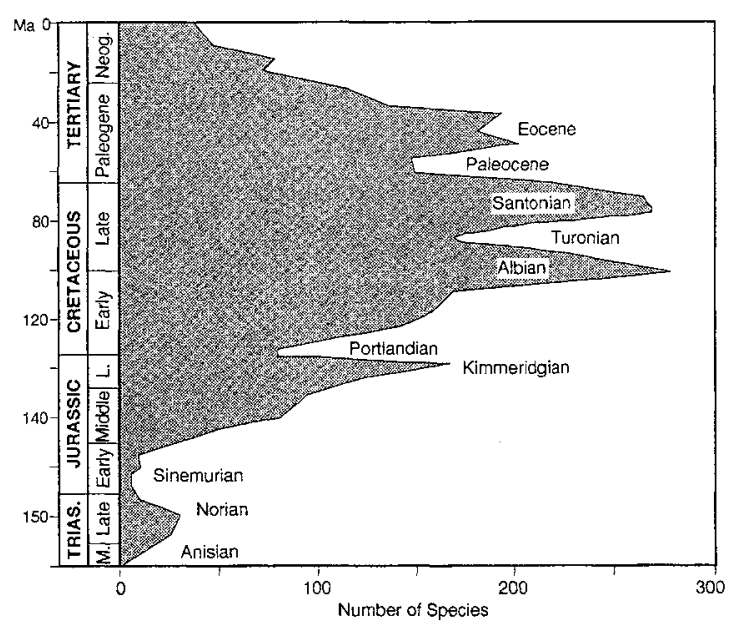

図 3 渦鞭毛藻化石の種数の層位変化 Williams and Bujak（1985）をとに改変。 


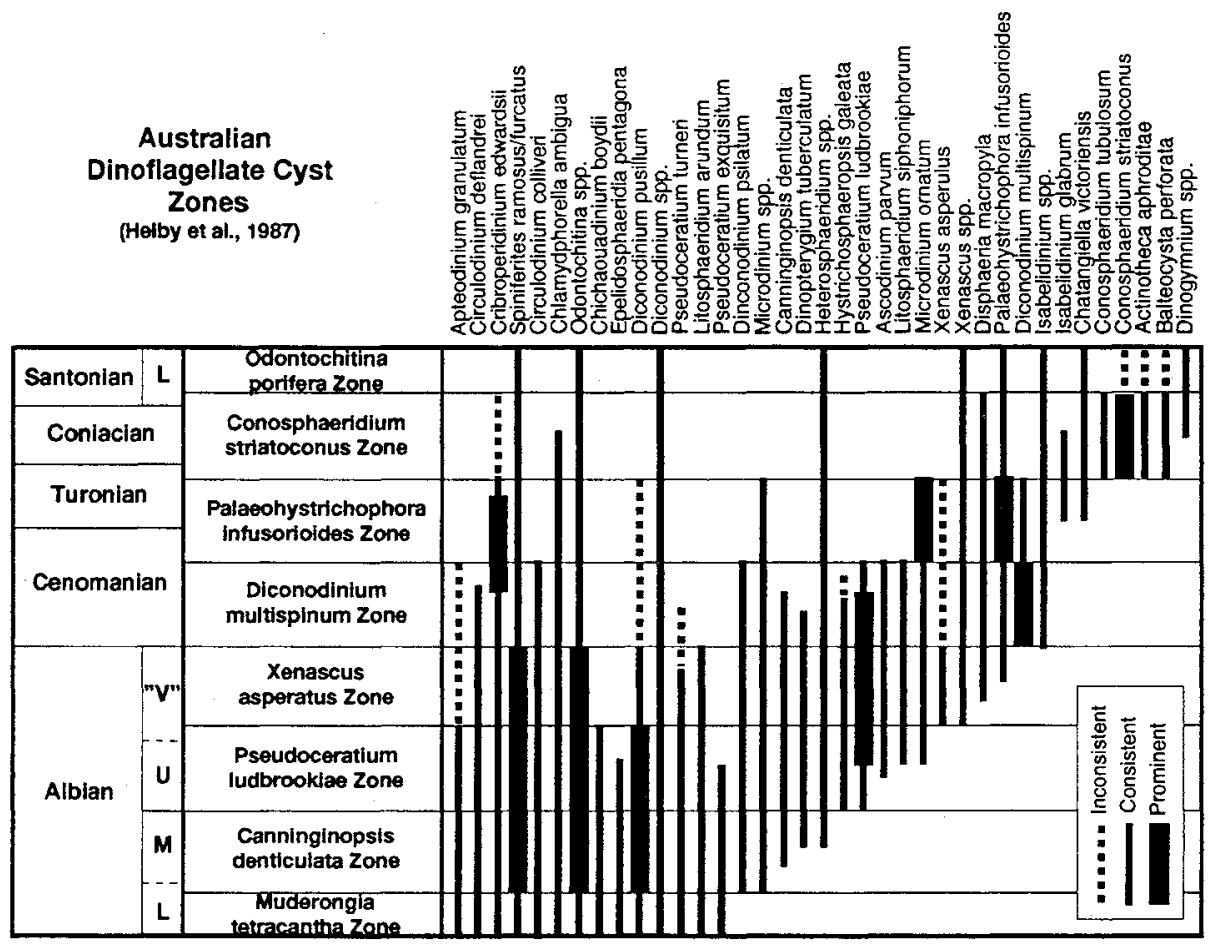

"V"=Vraconian, U=Upper, M=Middle, L=Lower

図 4 オーストラリアとその周辺地域における中生界渦鞭毛藻化石層序区分の一部（白亜系中〜上部）

Helby et al. (1987) を屯とに改変。

and Williams, 1980; Williams et al., 1990)。したがっ て一般に渦鞭毛藻化石層序は，基準面に基づく年代推定 上，地域ごとに確立された化石層序による対比・間接的 年代推定との双方を組み合わせることによって，最大限 に活用することができる。図 4 に示した白巠系中〜上部 の渦鞭毛藻化石帯区分（Helby et al., 1987）は, 300坑 井以上の石油操查坑井の資料に基づいて組み立てられた あので，オーストラリアとその周辺の広い地域で実用に 供されており，渦鞭毛藻化石層序が石油探鉱によく貢献 している一例である。これ以外に広域的な資料に基づい て渦鞭毛藻化石の層位分布をま之めた文献には，Williams and Bujak (1985), Bujak and Matsuoka (1986), Powell (1992), Williams et al. (1993), Stover et al. （1996）なごがある。

日本周辺では，1978 年に中国渤海湾の油田地域での 渦鞭毛藻化石群怙よび化石層序が記載されたのが，本格 的な渦鞭毛藻化石層序の利用の端緒である (Sung et $a l ., 1978) 。$ ほぼ同時期に松岡は日本各地の上部新生界 の渦鞭毛藻化石群抢よびその化石層序についての先駆的 な研究を行い（Matsuoka, 1974, 1976, 1979, 1983)，之の 化石層序観は1980年代後半に集成されて，北西太平洋沿
岸地域の上部新生界渦鞭毛藻化石層序の重要な基礎之 なっている(Bujak and Matsuoka, 1986 ; Matsuoka et al., 1987)。日本にお打る上部新生界以外の層準の化石 層序については，石油資源開発侏が1990年から独自の調 查研究を開始し，これまでに主として北海道において上 部白亜系〜古第三系の化石層序の大概を明らかにし，一 部を公表している（栗田・松岡， $1991 \mathrm{a}, \mathrm{b}, \mathrm{c}$; 栗田, 1994, 1995 ; Kurita and Matsuoka, 1994, 1996)。その成 果の一部は，北海道羽幌地域で永年論争のあった三毛別 層 ・羽幌層の層序問題の解決に寄与した（栗田ほか, 1992 ; 栗田・小布施，1994）。さらに，基礎試錐「天北」 において国内の石油試掘井では初めて掘削作業と並行し て連続した渦鞭毛藻化石分析が実施され，同試錐の層序 設定に貢献した（飯島，1996；栗田・小布施，1997）。 日本拉よびその周辺地域での渦鞭毛藻化石層序の利用 は，いまだ初期段階にあるものの，これまでに蓄積され た基礎資料之応用例は，渦鞭毛藻化石がこの地域での白 亜系〜新生界化石盾序ッールとして十分な分解能を持古 うることを明確に示している。最近では，北海道以外の 地域での渦鞭毛藻化石層序の応用例も現れている（栗田 ほか, 1996 ; 成田ほか, 1996 ; 小布施ほか，1996)。 
石油探鉱における渦鞭毛藻化石の利点は，(1)他の浮避 性微化石が産しないような浅海性堆積物からも豊富に産 出し，また堅硬な岩石からも抽出できるたわ，無化石試 料になりにくい；(2)特に中生界〜古第三系で層序分解能 が高い；(3)サイドウォールコアなど少量の試料です分析 が可能；(4)同じく有機質の微化石である花粉化石とは前 処理が共通で，両者の組み合わせに上り非海成相から深 海相までの広範な試料に対応できる；(5)露頭試料におい て風化の影響を他の微化石ほど受けない, などの点にあ る。これらの点は上記の諸例に見るように, 従来より微 化石の産出頻度が一般に低く，また良い示準化石に之し 加った北海道以北の第三系〜白亚系の探鉱にきわめて有 利に作用する。

\section{5. 渦鞭毛藻化石が示す古環境}

明らかに淡水性とされる渦鞭毛藻化石はごく少数の種 類が知られるのみで, 渦鞭毛藻化石の大多数は海生種で ある。したがって, 再堆積した向のでない限り, 渦鞭毛 藻化石の産出は一般に海成猿境を指示する。渦鞭毛藻化 石は内湾などの浅海成堆積物からも比較的高い頻度で産 出するので, 海成相と非海成相が互層するようなサクセ ション内での海成層準の検出に良い指標としてしばしば 用いられる(例えば Sweet and McIntyre, 1988)。

現世の沿岸表層堆積物中の渦鞭毛藻シスト群集につい ては，最近になって群集組成と海洋環境（特に海流と栄 養壏類の分布) との関係が詳しく論じられるようになっ た (Wall et al., 1977 ; Harland, 1983 ; Matsuoka, 1992 なよ゙)。地質時代の海域での古環境変化と関連づけた渦 鞭毛藻化石群集の解釈はまだ研究例が限られており, 今 後の研究の進展が期待される。既存の研究例には, 北米 の上部白垔系〜古第三系におりる渦鞭毛藻化石群集の多 様度や組成の層位変化と海進・海退の進行との相関につ いての報告 (Harland, 1973；Goodman, 1979； Kurita and McIntyre, 1994）や, 北海道石狩地域の幌内層・紅 葉山層に産するきわめて単調な渦鞭毛藻化石群集を内湾 性の停滞水塊との関連で解釉した例（Kurita and Matsuoka, 1994) などがある。

なお上述のように, 渦鞭毛藻シストの化石化過程はか なりの程度二次移動の影響を受けると考えられるため, 特に外側陸棚以深の環境下の堆積物中では渦鞭毛藻化石 群集と堆積罟境との関係の考察には注意が必要である う。渦鞭毛藻化石と古環境との関連の詳細については, Stover et al. (1996)・栗田ほか（1997）などを参照さ れたい。

\section{謝 辞}

石油資源開発株式会社には小論の公表を許可していた だいた。石油技術協会には，小論の内容の一部をシンポ ジゥムにおて発表する機会を与えていただいた。長崎 大学の松岡數充教授には，日ごろより想切なご指導を頂 いているほか，小論の作成中に多大なご教示を頂いた。 秋葉文雄氏には原稿を読んでいただき，ご批判を得た。 以上の機関・かたがたに衰心よりの謝意を表する。

\section{引用 文 献}

Bujak, J. P. and Matsuoka, K., 1986 : Late Cenozoic dinoflagellate cyst zonation in the western and northern Pacific. Amer. Assoc. Stratigraphic Palynologists Contrib. Ser., 17, 7-25.

Dale, B., 1992 : Dinoflagellate contributions to the open ocean sediment flux. In Honjo, S., ed. : Ocean biocoenosis, 5, 1-32, Woods Hole Oceanog. Inst. Press.

de Verteil, L. and Norris, G., 1996 : Miocene dinoflagellate stratigraphy and systematics of Maryland and Virginia. Micropaleontology, 42, supplement, 1-172.

Edwards, L. E., 1993 : Dinoflagellates. In Lipps, J. H., ed. : Fossil prokaryotes and protists, 105-127, Blackwell, Cambridge.

Eisenack, A. and Kjellström, G., 1964-1975 : Katalog der fossilen Dinoflagellaten, Hystrichosphären und verwandten Mikrofossilien : volume 1-2, with 6 supplements. 3834 p., E. Schweizerbart'sche Verlagsbuchhandlung, Stuttgart.

Evitt, W. R., 1961 : Observations on the morphology of fossil dinoflagellates. Micropaleontology, 7, 385420 .

Evitt, W. R., 1985 : Sporopollenin dinoflagellate cysts : their morphology and interpretation. 333 p., Amer. Assoc. Stratigraphic Palynologists Foundation, Dallas.

Fensome, R. A., Gocht, H., Stover, L. E. and Williams, G. L., 1991-1995: The Eisenack catalog of fossil dinoflagellates: New series, volume 1-3., 2004 p., E. Schweizerbart'sche Verlagsbuchhandlung, Stuttgart.

Fensome, R. A., Taylor, F. J. R., Norris, G., Sarjeant, W. A. S., Wharton, D. I. and Williams, G. L., $1993: A$ classification of living and fossil dinoflagellates. Micropaleontology Spec. Publ., 7, 351 p., Amer. Mus. Nat. Hist., Washington, D. C.

Fütterer, D., 1978 : Distribution of calcereous dinoflagellates in Cenozoic sediments of Site 366, Eastern North Atlantic. In Lancelot, Y., Seibold, E., et al., eds. : Init. Rep. D.S.D.P., 96, 709-737.

Goodman, D. K., 1979 : Dinoflagellate “communities” 
from the Lower Eocene Nanjemoy Formation of Maryland, USA. Palynology, 3, 169-190.

Goodman, D. K., 1987 : Dinoflagellate cysts in ancient and modern sediments. In Taylor, F. J. R., ed. : The biology of dinoflagellates, 649-722, Blackwell, Oxford.

Harland, R., 1973 : Dinoflagellate cysts and acritarchs from the Bearpaw Formation (Upper Campanian) of southern Alberta, Canada. Palaeontology, 16, 665706.

Harland, R., 1983 : Distribution maps of Recent dinoflagellate cysts in bottom sediments from the North Atlantic Ocean and adjacent seas. Palaeonto$\log y, 26,321-387$.

Head, M. J. and Wrenn, J. H., 1992, eds. : Neogene and Quaternary dinoflagellate cysts and acritarchs. Amer. Assoc. Stratigraphic Palynologists Foundation, College Station, 438 p.

Helby, R., Morgan, R. and Partridge, A. D., 1987 : A palynological zonation of the Australian Mesozoic. Mem. Assoc. Australasian Palaeontologists, 4, 1-94.

飯島 東, 1996 : 北海道の古第三系堆積盆の変遷. 地学 雑, 105, 178-197.

并上 勲, 1996 : 真核光合成生物の多様性をもたらした 6。. 科学, 66, 255-263.

Jan du Chêne, R., Masure, E. et al., 1986 : Guide pratique pour la détermination de kystes de dinoflagellés fossiles: le complexe Gonyaulacysta. Bull. Centres Rech. Explor.-Prod. Elf-Aquitaine, Mém., 12, $479 \mathrm{p}$.

栗田裕司, 1994 : 北日本古第三系の渦鞭毛藻化石層序の 概要。日本古生物学会1994年々会予稿集, 32 .

栗田裕司, 1995 : 北海道北部・上部白亜系の渦鞭毛藻化 石層序の予察. 日本古生物学会1995年々会予稿集, 120 .

栗田裕司・秋葉文雄 - 竹内 徹 - 加瀬友喜, 1996：ロシ ア・サハリン島南部の第三系渦鞭毛藻・珪藻化石層序 および漸新統一中新統境界。日本古生物学会1996年々 会予稿集, 135 .

栗田裕司・一八関鉄郎・平松 力, 1992 : 北海道羽幌地 域の三毛別層乙羽幌層の地質年代，地質雑，98，259266.

栗田裕司・松岡數充, 1991a：北海道夕張地域, 幌内層・ 紅葉山層の渦鞭毛藻化石群集. 日本古生物学会1991年 年会予稿集, 44 :

栗田裕司 - 松岡數充, 1991b：北海道白糠丘陵地域, 古 第三系の渦鞭毛藻化石群集.日本古生物学会第140回例 会予稿集, 25 .

栗田裕司・松岡數充，1991c：北海道古第三系に拈ける 渦鞭毛藻化石群集の層位的変化 (演旨). 石技誌， $\mathbf{5 6}$, 346 .

Kurita, H. and Matsuoka, K., 1994 : Trinovantedinium boreale Bujak-dominated dinoflagellate assemblages in Eocene-Oligocene stratified water in nor- thern Japan. Review of Palaeobotany and Palyno$\log y, 84,129-153$.

Kurita, H. and Matsuoka, K., 1996 : Biostratigraphy and floral breaks: Late Cretaceous-Quaternary dinoflagellate cyst record in northern Japan. $A b$ stracts 1996 Ann. Meeting Palaeont. Soc. Japan, 150.

栗田裕司・松岡數充・小布施明子, 1997 : 堆積環境指標 としての有機質微化石（パリノモルフ）。堆積学研究, $44,59-69$.

Kurita, H. and McIntyre, D. J., 1994 : Dinoflagellate assemblages and depositional environments of the Campanian Bearpaw Formation, Alberta. Bull. Geol. Surv. Can., 479, 67-83.

栗田裕司 - 小布施明子, 1994 ：北海道北部, 羽幌層の古 第三紀渦鞭毛澡化石・花粉化石亡その地質年代扔上び 堆積環境。地質雑, 100, 292-301.

栗田裕司・小布施明子, 1997 : 北海道北部，基礎試錐 「天北」に打ける第三系〜上部白車系有機質微化石層 序 (渦鞭毛藻化石. 花粉胞子化石). 石技誌, $62(1)$, $13-24$.

Lentin, J. K. and Williams, G. L., 1976 : A monograph of fossil peridinioid dinoflagellate cysts. Bedford Institute of Oceanography, Rep. Ser. BI-R-75-16, 237 p.

Lentin, J. K. and Williams, G. L., 1980 : Dinoflagellate provincialism with emphasis on Campanian peridiniaceans. Amer. Assoc. Stratigraphic Palynologists Contrib. Ser., 7, 147 p.

Lentin, J. K. and Williams, G. L., 1993 : Fossil dinoflagellates: Index to genera and species 1993 edition. Amer. Assoc. Stratigraphic Palynologists Contrib. Ser., 28, 856 p.

Matsuoka, K., 1974 : Some plant microfossils from the Miocene Fujiwara Group, Nara, central Japan. Trans. Proc. Palaeont. Soc. Japan, N. S., 94, 319-340.

Matsuoka, K., 1976 : Paleoenvironmental study of the Saho and the Saidaiji Formations from a view point of palynology. Mizunami Fossil Museum, Bull., 3, 99-117.

Matsuoka, K., 1979 : Hystrichokolpoma from Pleistocene sediments in Okinawa-jima, Japan. Review of Palaeobotany and Palynology, 28, 47-60.

松岡數充, 1980 ：渦鞭毛澡シスト一その分類上の意義につ いて.月刊地球, 2, 319-326.

Matsuoka, K., 1983 : Late Cenozoic dinoflagellates and acritarchs in the Niigata district, central Japan. Palaeontographica, B, 187, 89-154.

松岡數充, 1989 : 日本海溝セジメント・トラップ JT $\cdots 2$ 試料中のパリノモルフ群集. 月刊海洋, 21, 232-238.

Matsuoka, K., 1992 : Species diversity of modern dinoflagellate cysts in surface sediments around the Japanese islands. In Head, M. J. and Wrenn, J. H., eds. : Neogene and Quaternary dinoflagellate cysts and acritarchs, 33-53, Amer. Assoc. Stratigraphic 
Palynologists Foundation, Dallas.

Matsuoka, K., Bujak, J. P. and Shimazaki, T., 1987 : Late Cenozoic dinoflagellate cyst biostratigraphy from the west coast of northern Japan. Micropaleontology, 33, 214-229.

Matsuoka, K., Kobayashi, S. and Gaines, G., 1990 : A new species of the genus Ensiculifera (Dinophyceae); its cyst and motile forms. Bull. Plankton Soc. Japan, 37, 127-143.

村田道雄, 1996 ：渦鞭毛藻とアレロケミックス，化学と 工業, 49, 1029-1031.

成田耕一郎・山路 敦・田上高広・小布施明子・栗田裕 司，1996：始新統と中新統からなる久万層群．日本地 質学会第103年学術大会講演要旨, 244 .

小布施明子 - 栗田裕司 -八木下晃司, 1996 ：北部北上山 地種市地域加らの第三紀花粉化石・渦鞭毛藻化石群集 と堆積相. 日本地質学会第103年学術大会講演要旨, 105.

Powell, A. J., 1992, ed. : A stratigraphic index of dinoflagellate cysts. 290 p., Chapman \& Hall, London.

Stover, L. E., Brinkhuis, H., Damassa, S. P., de Verteil, L., Helby, R. J., Monteil, E., Partridge, A. D., Powel1, A. J., Riding, J. B., Smelror, M. and Williams, G. L., 1996: Mesozoic-Tertiary dinoflagellates, acritarchs and prasinophytes. In Jansonius, J. and McGregor, D. C., eds. : Palynology: principles and applications. Amer. Assoc. Stratigraphic Palynologists Foundation, $641-750$.

Stover, L. E. and Evitt, W. R, 1978: Analyses of pre-Pleistocene organic-walled dinoflagellates. Stanford University Publications, Geol. Sci., 15, 300 p.

Stover, L. E. and Williams, G. L., 1987 : Analyses of Mesozoic and Cenozoic organic-walled dinoflagellates 1977-1985. Amer. Assoc. Stratigraphic Palynologists Contrib. Ser., 18, 243 p.

Sung Zhi-Chen et al., 1978: On the Paleogene dino- flagellates and acritarchs from the coastal region of Bohai. 190 p., Science Press, Beijing. (in Chinese)

Sweet, A. R. and McIntyre, D. J., 1988 : Late Turonian marine and nonmarine palynomorphs from the Cardium Formation, north-central Alberta Foothills, Canada. In James, D. P. and Leckie, D. A., eds. : Sequences, stratigraphy, sedimentology: surface and subsurface, Can. Soc. Petrol. Geol., Mem., 15, 499-516.

Wall, D., Dale, B., Lohmann, G. P. and Smith, W. K., 1977 : The environmental and climatic distribution of dinoflagellate cysts in modern marine sediments from regions in the North and South Atlantic Oceans and adjacent seas. Marine Micropaleontology, 2, 121-200.

Williams, G. L., Ascoli, P., Barss, M. S., Bujak, J. P., Davies, E. H., Fensome, R. A. and Williamson, M. A., 1990 : Biostratigraphy and related studies. In Keen, M. J. and Williams, G. L. eds. : Geology of the continental margin of eastern Canada, Geology of Canada, 2, 87-137, Geol. Surv. Can., Ottawa.

Williams, G. L. and Bujak, J. P., 1985 : Mesozoic and Cenozoic dinoflagellate cysts. In Bolli, H. M., Saunders, J. B. and Perch-Nielsen, K., eds. : Plankton stratigraphy, 847-964, Cambridge Univ. Press, Cambridge.

Williams, G. L., Stover, L. E. and Kidson, E. J., 1993 : Morphology and stratigraphic ranges of selected Mesozoic-Cenozoic dinoflagellate taxa in the Northern Hemisphere. Geol. Surv. Can. Paper, 92-10, 137 p.

Wrenn, J.H., Duffield, S. L. and Stein, J.A., 1986, eds. : Papers fom the First Symposium on Neogene dinoflagellate cyst biostratigraphy. Amer. Assoc. Siratigraphic Palynologists Contrib. Ser., 17, 229 p. 